\title{
Cervical Cancer pT2b TNM Finding v7
}

National Cancer Institute

\section{Source}

National Cancer Institute. Cervical Cancer pT 2b TNM Finding v7. NCI Thesaurus. Code C89539.

Cervical cancer invades beyond uterus but not to pelvic wall or to lower third of vagina.

Parametrial invasion is present. (from AJCC 7th Ed.) 